\title{
The content of terpinen-4-ol in the essential oil of separate leaves and in hydrodistilled oil of leaves and terminal twigs of Juniperus communis L. var. saxatilis Pall.
}

\author{
Jan Karlsen, Anders Bærheim Svendsen \\ Department of Pharmaceutics, Faculty of Sciences \\ University of Oslo, P.O.Box 1068, 0316 Oslo, Norway
}

\begin{abstract}
Investigations with solid sampling gaschromatography of separate leaves and of hydrodistilled oil of Juniperus communis L. var. saxatilis Pall. growing in Norway at an altitude of $1000-1300 \mathrm{~m}$ above sea level, showed a terpinen-4-ol content varying from traces to about $1 \%$ in separate leaves and up to $16-17 \%$ in hydrodistilled oil of uncomminuted leaves and twigs.
\end{abstract}

\section{Key Words}

Juniperus communis L.var. saxatilis Pall., Cupressaceae.

\section{Introduction}

During our investigations on the influence of the isolation method on the results of the determination of the essential oil of leaves and twigs of Juniperus communis L. var. saxatilis Pall. (1), we observed remarkable variations in the terpinen-4-ol content of the oil depending on whether the plant material was comminuted or not prior to the distillation, as well as depending upon the duration of the distillation. Under 'mild' distillation conditions (comminuted plant material, addition of calcium carbonate to the distillation water to prevent interactions of the plant acids present and a duration of the distillation of 15-30 minutes) the terpinen-4-ol content of the oil was found to be $1-1.5 \%$, whereas hydrodistillation of uncomminuted material for 2-4 hours yielded oil samples with $10-17 \%$ terpinen-4-ol. In order to find out whether the remarkable increase in the terpinen-4-ol content was due to the duration of the hydrodistillation, we tried to find out how the situation was in separate leaves of the plant using solid sampling gaschromatography, as described in previous papers (2-7). Since an increase in the terpinen-4-ol content to some degree seemed to go parallel with a decrease in the sabinene content, we found it of interest to include sabinene in the present investigation. 


\section{Material and methods}

Leaves and terminal twigs of Juniperus communis L. var. saxatilis Pall. were collected in the province Valdres in Central Norway at two habitats and at different seasons of the year, one at Kruk at about $1000 \mathrm{~m}$ above sea level during the winter, the shrubs were covered by $1 \mathrm{~m}$ of snow, the second one at Kruk in May and the third one at Smørli at about $1300 \mathrm{~m}$ during August. May and August mean late spring for the shrubs in question at the altitudes mentioned. The plant material was analysed as soon as possible or kept at $-20^{\circ} \mathrm{C}$ until analysed.

\section{Solid sampling gaschromatography}

The plant material, one or two leaves, was placed in a 'basket' of stainless steel. The 'basket' was connected with a stainless steel rod going through a metal tube with gas tight teflon O-rings. The 'basket' was moved into the injection port of the gaschromatograph and - after some seconds removed.

We found that satisfactory analytical results were obtained when using an injector temperature of $200^{\circ} \mathrm{C}$ and an injection time of 12 seconds. Lower injector temperatures and shorter injection times lead to incomplete evaporation, and higher injector temperatures and longer injection times to transformation of some of the constituents (6).

\section{Gaschromatography}

A $30 \mathrm{~m}$ long J\&W Scientific DB-fused silica column, $0.25 \mathrm{~mm}$ I.D., film thickness $0.25 \mu \mathrm{m}$, was used in a Shimadzu GC-14A system; carrier gas was helium, flow rate $2 \mathrm{ml} / \mathrm{min}$, injector temperature $200^{\circ} \mathrm{C}$, detector $240^{\circ} \mathrm{C}$; essential oil samples were injected in hexane solutions in the split mode (1:20); column temperature: programming $60^{\circ} \mathrm{C}$ to $240^{\circ} \mathrm{C}, 3^{\circ} \mathrm{C} / \mathrm{min}$.

\section{Results and discussion}

The results obtained by solid sampling gaschromatography of the essential oil present in separate leaves of Juniperus communis L. var. saxatilis Pall. growing in Norway, seem to suggest that the terpinen-4-ol often found in amounts up to $15-17 \%$ in oils isolated by long lasting hydrodistillations, is formed by sabinene and other compounds occurring in the oil. 
Table 1. Percentage content of sabinene and terpinen-4-ol in separate leaves of Juniperus communis L. var. saxatilis Pall. obtained by solid sampling gaschromatography.

\begin{tabular}{|c|c|c|}
\hline $\begin{array}{c}\text { Origin of } \\
\text { plant material }\end{array}$ & Sabinene & Terpinen-4-ol \\
\hline Kruk Winter & 57,9 & 0,2 \\
\hline & 58,6 & $\mathrm{tr}$ \\
\hline Kruk May & 53,3 & 0,2 \\
\hline & 64,5 & $\mathrm{tr}$ \\
\hline & 46,5 & 0,1 \\
\hline & 56,9 & 0,3 \\
\hline & 56,8 & 0,1 \\
\hline & 46,5 & 0,2 \\
\hline & 62,3 & 0,3 \\
\hline Smørli August & 41,6 & 0,4 \\
\hline & 53,5 & 0,5 \\
\hline & 46,5 & 0,4 \\
\hline
\end{tabular}

\section{References}

[1.] Karlsen, J., Bærheim Svendsen, A. Sci.Pharm. 2002; 70:87.

[2.] Bærheim Svendsen, A., Karlsen, J. Planta Med. 1967; 14:367.

[3.] Karlsen, J., Bærheim Svendsen, A. Planta Med. 1968; 16:95.

[4.] Karlsen, J., Bærheim Svendsen, A. Medd. Nor. Farm. Selsk. 1968; 30:1.

[5.] Karlsen, J., Bærheim Svendsen, A., Chingova, B., Zolotovitch G.

Planta Med. 1969; 17:281.

[6.] Rasmussen, K.E., Rasmussen, S., Bærheim Svendsen, A.

Sci.Pharm. 1972; 40:17.

[7.] Karlsen, J. J. Chromatogr. 1974; 90:285. 